\title{
Tradition and Islamic Philosophy: Some Recent Urdu Publications on Mullā Ṣadrā
}

\author{
Sajjad Rizvi \\ University of Exeter \\ s.h.rizvi@exeter.ac.uk
}

\begin{abstract}
The reception of Mullā Șadrā in South Asia began soon after his death through the dissemination and commentary culture on his Sharh al-Hidāyah that was adopted into the Dars-e Niẓāmī pedagogy in the eighteenth century. However, the modern reception of his thought in Urdu has been somewhat removed from that initial scholastic engagement. I examine four modalities of this reception: translation of his major work the Asfär; analytic engagement by a philosophy doctorate; triumphalism in the literary sphere; and responses to the intellectual challenge of the West by a Shici seminary student. I attempt to show that these varied receptions are indicative of trends and developments in the modern intellectual history of Pakistan.
\end{abstract}

\section{Keywords}

Islamic philosophy - Mullā Șadrā - analytic philosophy - Urdu translation

On Friday, December 24, 2010, the Hikmah Foundation, represented by Maulana Syed Salman Naqavi and chaired by the well-known journalist and intellectual Aneeq Ahmed, convened an Urdu conference at the Sheikh Zayed Institute of Islamic Studies at Karachi University on the famous Safavid thinker and eminent philosopher of the late classical period, Mullā Ṣadrā Shīrāzī (d. 1636). Titled "Man and Transcendent Philosophy," the conference featured two keynote speakers: the prominent traditionalist Deobandi speaker Ahmed Javed and the leading Shi'i ḳhațīb (orator) Syed Aqeel ul-Gharavi. ${ }^{1}$ Various

1 There were around nine speakers from academia and from Shici and Sunni seminarians. Some of the videos of the talks are available on YouTube; see, for example, Ahmed Javed,

(C) SAJJAD RIZVI, 2020 | DOI:10.1163/26659050-12340002

This is an open access article distributed under the terms of the CGG BY 4.0 License. 
dailies including the Dawn wrote up the conference focusing on Mullā Șadrā's contribution to philosophy and human knowledge. ${ }^{2}$ While almost by definition an elite and rather restricted event, the conference demonstrates the two tendencies of interest in Mullā Șadrā in contemporary Urdu literary culture in South Asia: first, a continuation of the focus on the rational disciplines of the seminary in North India, on the ma'qülät within the pedagogy known as the Dars-e Nizāmī; and, second, a modern interest in philosophy within learned culture-further motivated by the rise of the philosophy of Mullā Șadrā in Iran since 1979-attempting to find an "Islamic philosopher" who can be championed in identity politics to illustrate that Muslims, especially Pakistanis, also can do philosophy. ${ }^{3}$ This latter tendency brings together Shi'i religious leaders and functionaries who have trained in the seminary in Qum in the postrevolutionary period, as well as intellectuals seeking, via engagement with the postmodern debate on the nature of philosophy, an "Islamic" authentic alternative to the analytic tradition of philosophy. While it is evident that in a post1979 period, the public debate on Islam, reason, and authenticity has become more sectarianized, it is striking that such an event and attempt to disseminate Mullā Ṣadrā in contemporary Pakistan has not sought to restrict its scope to the Shici communities or Shi'i intellectuals alone. ${ }^{4}$ These tendencies to make sense

"Man \& The Transcendent Philosophy—Ahmad Javaid," YouTube, October 6, 2015, https:// youtu.be/c2 $\mathrm{G}_{3} \mathrm{SAsSIvk}$; or the following video in which Javed discusses his own life and the role of philosophy: "Ahmad Javed sb tells his life story," YouTube, September 5, 2016, https:// youtu.be/yCMO3do5oyA. On Syed Aqeel ul-Gharavi, see this interview with Aneeq Ahmed on Dunya TV: "Ayatullah Aqeel ul Gharavi exclusive interview on DUNYA TV," YouTube, June 29, 2012, https://youtu.be/rU27jDBJoj4.

2 "Mulla Sadra's contribution to philosophy highlighted," Dawn, December 24, 2010, https:// www.dawn.com/news/593377. Aneeq Ahmed is well known in the media for hosting religious, political, and theological programming. After a time as a student activist with the Jami'at-e Talabah-e Islām at Karachi University, he graduated with an MA in International Relations in 1989. He joined PTV in 1999 and has been with Dunya TV since 2011.

3 In Iran and in Persian, this is done through the many comparative studies pitting Mullā Șadrā in a triumphalist manner against any number of European thinkers from Leibniz, Kant, and Hegel to Tillich. See 'Alī-Aṣgghar Zakavī, Basịț ul-Haqīqah az Dīdgāh-e Mullā Ṣadrā o Monādolojī-e Lä̉ibnitz (Qum: Bustān-e kitāb, 1384 Sh/2005); Muhammad Fanāīi-Ashkivarī, Máqūl-e Śānī: Tahlī̄ì az Anvā'-e Mafāhīm-e Kullī dar Falsafah-e Islāmī o Ġharbì (Qum: Mu’assasah-e Āmozishī o Pazhūhishī-e Imām Ḳhumainī, 1387 Sh/2008); Hamidreza Ayatollahy, The Existence of God: Mulla Sadra's Seddiqin Argument versus the Criticisms of Kant and Hume (Tehran: Sadra Islamic Philosophy Research Institute, 2004); A'lā' Tūrānī, Ķhudā az Dìdgāh-e Șadr ul-Mutảallihīn o Pāl Tiliḳh (Tehran: Mu’assasah-e Farhangīee Dānish o Andīshah-e Muāșir, $1383 \mathrm{Sh} / 2004)$. For a discussion of this phenomenon, see my Mullā Șadrā and Metaphysics: Modulation of Being (London: Routledge, 2009), 8-14.

4 See Muhammad Qasim Zaman, "Sectarianism in Pakistan: The Radicalisation of Sunni and Shi'i Identities," Modern Asian Studies 32 no. 2 (1998), 689-716; Farzana Shaikh, Making Sense of Pakistan (New York: Oxford University Press, 2018), 81-115, 147-179; Andreas Rieck, The Shias 
of public reason, to articulate a need for philosophy, and to think that through in an existentialist and post-colonial search for authenticity and possibility in contemporary Pakistan are critical to the works on Mullā Șadrā produced in Urdu in recent years. But before we analyze the uses of the Safavid philosopher in modern Pakistan, we need some context in which to locate them.

Within South Asia, at least since the eighteenth century, reception of the works and thought of Mullā Șadrā has taken on different forms. The first is the incorporation of the natural philosophy section of his commentary on the Hidāyat ul-Hikmah (Guidance in Philosophy) of Asīr ud-Dīn al-Abharī (d. 1265) into the pedagogy of the Dars-e Nizāmi associated with the scholar from Lucknow in Mughal service, Mullā Nizạām ud-Dīn Sihālvī (d. 1748). ${ }^{5}$ This section was first published in Lucknow in 1262/1846 and reprinted numerous times from Lucknow and Delhi, often with one or another famous gloss. ${ }^{6}$ By contrast, the number of manuscripts of the text in Iran is far smaller, with the first lithograph being produced in Tehran in 1313/1896. The adoption of this text speaks to the popularity of Avicennian physics in North India. ${ }^{7}$ There are over one hundred extant glosses in Arabic on the text; the earliest glosses on the Sharh ul-Hidāyah were already being written in the late seventeenth century by Pīr Muhamammad Jaunpūrī (d. c. 1085/1674) and Qāẓī Ișmatullāh Lakhnavi (d. 1113/1701). The latter is extant in one codex at the Khuda Bakhsh Library in Patna. ${ }^{8}$ The first sustained engagement with Mullā Șadrā's thought in India, albeit not in the form of a commentary, was in the theological corpus

of Pakistan: An Assertive and Beleaguered Minority (London: Hurst \& Co., 2015), 18off; Simon Wolfgang Fuchs, In a Pure Muslim Land: Shi ism between Pakistan and the Middle East (Chapel Hill: University of North Carolina Press, 2019), 152-185.

5 On Mullā Nizạām al-Dīn and the Dars-e Niz̄āmī, see Muftī Riẓā Anșārī, Bānī-e Dars-e Nizāām Ustād ul-Hind Mullā Niz̄ām ud-Dīn Muhammad Farangī-Mahallī (Aligarh: Aligarh Muslim University, 1973), 257-265; Jamīl Ahmad, Harakat al-Ta'līf bi'l-Lughat al-Arabiyyah fíl-Iqlìm al-Shimālī al-Hindī (Karachi: Jāmi'at al-Dirāsāt al-Islāmiyyah, n.d.), 17-22; Alțāf ur-Raḥmān

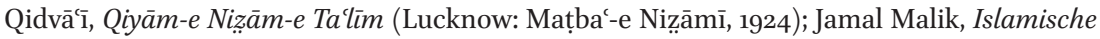
Gelehrtenkultur in Nordindien: Entwicklungsgeschichte und Tendenzen am Beispielvon Lucknow (Leiden: Brill, 1997), 522-535; Qamar ud-Dīn, Hindustān kī Dīnī Darsgāheñ (New Delhi: Hamdard Education Society, 1996), 345-352; Aḳhtar Rāhī, Tazkirah-e Mușannifin-e Dars-e Niz̄āmī (Lahore: Maktabah-e Raḥmāniyyah, 1978); Sayyid Manāẓir Aḥsan Gīānī, Hindustān meñ Musalmānoñ kā Nizāam-e Tálìmo Tarbiyat (New Delhi: Nadwat ul-Muṣannifīn, 1966); Asad Q. Ahmed, "Dars-i Nizāāmī," Encyclopaedia of Islam, Three, accessed June 8, 2019, http://dx.doi.org/10.1163/1573-3912_ei3_COM_27350.

6 Ṣadr ud-Dīn Shīrāzī, Sharḥ-e Hidāyat ul-Hikmah (Lucknow: Maṭba'-e 'Alawī, 1262 Sh/1846).

7 Jon McGinnis, "Pointers, Guides, Founts and Gifts: The Reception of Avicennian Physics in the East," Oriens 41 (2013): 433-456; Asad Q. Ahmed, "The Shifä' in India: Reflections on the Evidence of the Manuscripts," Oriens 40 (2012): 199-222.

8 'A. Ma'ṣūmī, "Șadr al-Dīn Shīrāzī: Ḥayātuhu va Āsāâruhu," Indo-Iranica (Calcutta), 14 (1961): 27-42; Akbar Ṡubūt, "Sharḥ-e Hidāyah-e Mullā Șadrā," Ḳhiradnāmah-e Șadrā 3 (1375 Sh/1996), 100-107; Akbar Śubūt, Fīlsūf-e Shīrāz dar Hind (Tehran: Intishārāt-e Hirmis, 2001), 7-8. 
of Sayyid 'Alī Ḳhān Madanī (d. 1120/1709), the famous scion of a Shirazi family, who lived in Hyderabad in the Deccan (via Medina) and wrote prolifically in Arabic. Sometimes he cites Mullā Șadrā directly and sometimes he does so indirectly by quoting one of his illustrious philosophical forebears from the Dashtakī family. ${ }^{9}$

After that stage, in which the engagement with Mullā Șadrā was mainly in the scholastic mode of the Arabic commentary tradition, the embrace of his thought by modernist thinkers, in Urdu and in English, in the colonial period was noticeable and brought his ideas to the attention of the literary classes, not least as they grappled with aspects of their literary and intellectual heritage. The first history of philosophy in Urdu, which appeared in 1879, the Mir'ät ul-Hukamā’ yā Guldastah-e Farang (Mirror of Philosophers) by Sayyid Imdād Imām "Aṡar" (1849-1934), a prominent notable of Patna, was more an attempt to bring the contributions of European philosophy-especially the "direct realism" of Thomas Reid (1710-1796) and Sir William Hamilton (1788-1856), as well as the later idealism of the British universities— to the world of the Dars-e Niżāmi-trained 'ulamā. ${ }^{10}$ Because of his importance to the history of literature and linguistics through his work Käshif ul-Haqā̇iq yā Bahäristān-e Sukhan, first printed in Bihar by Star of India Press in 1877, his philosophical work became known. ${ }^{11}$ Imām mentions Mullā Ṣadrā very briefly and in an indexical manner.

9 Subūt, Fīlsūf-e Shīrāz dar Hind (Tehran: Intishārāt-e Hirmis, 2001), 13-20.

10 Sayyid Imdād Imām "Aṡar," Mirat ul-Hukamā yā Guldastah-e Farang (Patna: Șubḥ-e Șādiq Press, 1879). Both Reid and Hamilton were occupied with studying the nature of the mind and its relation to the cosmos. Direct realism, or "common sense realism," is identical to the more recent exposition of "naïve realism" that posited a world of mindindependent objects that we can access through our sense-perception. See Hilary Putnam, The Threefold Cord: Mind, Body, and World (New York: Columbia University Press, 200o), and John R. Searle, Seeing Things as They Are: A Theory of Perception (Oxford: Oxford University Press, 2015). On the importance of the British idealism of T.H. Green (1836-1882), F.H. Bradley (1846-1924), and Bernard Bosanquet (1848-1923), see Philip Ferreira, "Idealist Logic," Pierfranceso Basile, "Bradley's Metaphysics," and William Sweet, "British Idealist Philosophy of Religion," in The Oxford Handbook of British Philosophy in the Nineteenth Century, ed. W.J. Mander (Oxford: Oxford University Press, 2014), 111-133, $189-208,560-583$.

11 There is surprisingly little on a person who was a first in many areas, not least the first to write a history of philosophy in Urdu, the first Urdu work on fruit trees, and the first Urdu biography of Queen Victoria. There are two studies on him: Sarvar ul-Hudā, Imdād Imām Aśar: Adabiyāt, Tașavvurāt, aur Nau Adabiyāt (New Delhi: Ġhālib Institute, 2017), and Imtiyāz 'Ālam, Imdād Imām Aṡar: Shaḳhṣiyat aur Tanqūdī Taṣavvurāt (New Delhi: Educational Publishing House, 2014); Aḳhtar Qādirī, "Hālāt-e Zindagī," in Dīvān-e Imdāad Imām Aśar, ed. Sarvar ul-Hudā (New Delhi: Ġhālib Institute, 2013), 9, citing Sir Roper Lethbridge, The Golden Book of India: A Genealogical and Biographical Dictionary of the Ruling Princes, Chiefs, Nobles and Other Personages (Edinburgh: R\&R Clark, 1893), 190. 
Imām's work was followed by the forays into Islamic intellectual history by Shiblī Nu'mānī (1857-1914), who described the circles of the study of philosophy in Lucknow as the "Cambridge of India," and then the influential dissertation of Muhammad Iqbal (1877-1938), The Development of Metaphysics in Persia, awarded a doctorate in Munich in $1908 .{ }^{12}$ Other figures of this period familiar with philosophy such as 'Abd ul-Mājid Daryābādī (1892-1977), who had a BA in Philosophy from Canning College, Lucknow, and an MA in Philosophy from Aligarh Muslim University, turned his attention more to the reception of Anglophone psychology than to any attempt to disseminate the teachings of Mullā Șadrā. ${ }^{13}$ Iqbal was the first to write about Mullā Șadrā in English and to bring his thought to the attention of modernists in South Asia and beyond. There was not much direct engagement with Mullā Șadrā—more with his later commentator Hādī Sabzavārī (1797-1873), revealing Iqbal's relative comfort with Persian in comparison to Arabic. Yet the work reveals a stage in Iqbal's quest for an existentialist and personalist philosophy for which he treats Mullā Șadrā’s "unity-in-diversity" metaphysics as a stage in both Persian thought and Platonism that aligns with forms of German idealism. ${ }^{14}$ It is perhaps a truism that since all intellectual history is presentist, the ways in which Iqbāl instrumentalizes Mullā Șadrā are clearly in light of his contemporary concerns.

Although Iqbal's modernist philosophical work was in English, he influenced thinkers in both English and Urdu. In the former category were the leading philosophers of post-independence Pakistan: Mian Mohammed Sharif (1893-1965), Chaudhury Abdul-Qadir (1909-1987) and Khalifah Abdul-Hakim (1894-1959). Sharif had studied philosophy at Aligarh before partition and then did his PhD in analytic philosophy with G.E. Moore (1873-1958) at Cambridge. On return to Pakistan, he taught for many years in Lahore and was the

See also Nasir Abbas Nayyar, "The Forgotten Litterateur," The News, accessed September 30 , 2018, http://tns.thenews.com.pk/forgotten-litterateur/\#.XPjwPC2ZO1s. The text of the Kāshif was reprinted many times: typeset in 1913 by Munshī Muhammad Nasīm (Lucknow: Coronation Press), then edited by Vahhāb ul-Ashraf (New Delhi: Taraqqī-yi Urdu Bureau, 1982), and then reprinted (New Delhi: Educational Publishing House, 1994, 2004).

12 Shiblī Nu'mānī, Maqālāt-e Shiblī (Azamgarh: Dār ul-Mușannifīn, 2009), 3:98-129, 141-162.

13 'Abd ul-Mājid Daryābādī, Āp-Bìtī (Lucknow: Maktabah-e Firdaws, 1978), 112-130. Daryābādī's main philosophical contribution lay in psychology: Falsafah-e Ijtimāa ya'n̄̄

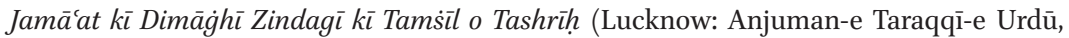
1915) and Falsafah-e Jażbāt (Aurangabad: Anjuman-e Taraqqī-e Urdū, 1920).

14 Muhammad Iqbal, The Development of Metaphysics in Persia (London: Luzac \& Co., 1908), 134-143; Sajjad Rizvi, "Between Hegel and Rumi: Iqbal's Contrapuntal Encounters with the Islamic Philosophical Traditions," in Muhammad Iqbal: Essays on the Reconstruction of Modern Muslim Thought, ed. H.C. Hillier and Basit Koshul (Edinburgh: Edinburgh University Press, 2015), 122-127. 
founding president of the Pakistan Philosophical Congress in 1951. Qadir, a leading "analytic modernist," played a major role in translating works of psychology and philosophy from the analytic tradition into Urdu. He also did much to bring the insights of Rūmī and Iqbāl into conversation with the analytic tradition. ${ }^{15}$ Abdul-Hakim wrote mainly in English and was heavily influenced by Iqbāl as evidenced in his PhD at Heidelberg in 1925 on the metaphysics of Rūmī. In India, he taught at Osmania University; once in Pakistan, he became the first head of the Iqbal Academy as well as the Institute of Islamic Culture (IIC, Idārah-e saqāfat-e islāmiyah). Established in 1952 in Lahore as a semi-governmental organisation that was deliberately nondenominational, the IIC became an institution where Abdul-Hakim promoted both modernism and Sufism (which were often considered antithetical even in the thought of Iqbāl). Sharif succeeded him as the head of the IIC. ${ }^{16}$ On the more "Islamic" side of the legacy of Iqbāl which engaged with the ma'qülät tradition of Northern India was the work of Waheed Ishrat (d. 2009), former Deputy Director of the Iqbal Academy. Ishrat wrote a number of works on concepts in Islamic philosophy and edited volumes taking in translations into Urdu of Mullā Ṣadrā, 'Abd ul-Ḥaqq Ḳhairābādī, and others, to articulate an "authentic" Islamic (Pakistani) philosophy. ${ }^{17}$ The works of Abdul-Hakim

15 His works included Islamic Philosophy of Life and Its Significance (Lahore: Progressive Publishers, 1970), heavily influenced by existentialism; Islamic Philosophy and Science (London: Routledge, 1992), a useful analyticising introduction to the topic; various textbooks in English for his philosophy students such as Logical Positivism (Lahore: Pakistan Philosophical Congress, 1965), Philosophy of Science (Lahore: Pakistan Philosophical Congress, 1971), Knowledge of Other Minds (Lahore: Pakistan Philosophical Congress, 1959); and various textbooks in Urdu such as Ma'ārif-e Manțiq-e Jadìd (Karachi: Shu'bah-e Tașnïf o Ta'lif o Tarjumah-e Karachi University, 1965) on the logic of Whitehead and Russell that includes a brief preface on Arabic logic texts and their terminology, Nafsiyyāt (Lahore: West Pakistan Urdu Academy, 1965) on empiricist American psychology, Mu'āshirī Nazariye (Lahore: West Pakistan Urdu Academy, 1967) on social psychology from Ibn-e Ḳhaldūn through Malthus to Durkheim and Weber.

16 Some of his works included: Ḳhalīfah 'Abd ul-Ḥakīm, Iqbāl aur Mullā (Lahore: Bazm-e Iqbāl, n.d.) on healthy anti-clericalism; Fikr-e Iqbāl (Lahore: Bazm-e Iqbāl, rpt., 1983) on the contours of Iqbāl's thought especially on selfhood; Islam and Communism (Lahore: Institute of Islamic Culture, 1951) on a robust alternative to communism which included some of the earliest writings in English on Islamic economics; Islamic Ideology (Lahore: Institute of Islamic Culture, 1951) on consequentialist ethics as the core of Islamic values and on theism, written as a textbook on Islam; The Metaphysics of Rūmī (Lahore: Institute of Islamic Culture, 1965), his Heidelberg Ph.D. On Abdul-Hakim himself, see Muhammad Qasim Zaman, Islam in Pakistan: A History (Princeton: Princeton University Press, 2018), 58-59, 93-94, 208-210.

17 Vahị̄ 'Ishrat, Pākistānī Saqāfat kī Tashkīl (Lahore: Pākistānī Falsafah, 1977); Khair o Sharr (Lahore: Sang-e Meel, 2007); Zamān o Makān (Lahore: Sang-e Meel, 199o); Jabr o Qadr 
and Ishrat in particular remain in print and are popular. If one considers one important snapshot of philosophy in Pakistan-the volume published in 1998, edited by Naeem Ahmed, professor of philosophy at the University of Punjab-one sees the coming together of those wishing to instrumentalize the intellectual traditions (from Mullā Șadrā to Iqbāl) for their modernist agendas, as well as those attempting to bridge analytic and Islamic philosophy, alongside others with no desire to take the traditions seriously. ${ }^{18}$ The philosophical scene in Pakistan is not simply pitting "traditionalists" defending the Dars-e Nizämis approach to the Islamic philosophical tradition against modernist analytic philosophers, but rather constituted by a spectrum of positions motivated by, though transcending, this binary.

Glimpses and citations of Mullā Ṣadrā are therefore found in a variety of writings in Urdu literary culture, not least among commentators and critics such as Muhammad Ḥasan 'Askarī (1919-1978). Although he resisted the use of Mullā Șadrā in the attempted existentializing mode of Iqbāl, his increasing alignment with the monism of Ibn ul-'Arabī and the philosophical interests of the scholastics, such that he defined the Urdu literary tradition in those terms, placed him among the literary figures who engaged Mullā Șadrā as an essential part of the authentic Islamic, Sufi traditions of Northern India. ${ }^{19}$ This confluence of Sufism, scholasticism and modernism-further enhanced with postmodernism - is evidenced in the work of the contemporary critic Nāșir 'Abbās Nayyar, which somehow recalls the work of Arabic literary figures like Adonis (b. 1930). ${ }^{20}$ Thus Mullā Șadrā becomes part of that tradition of authentic culture that is engaged and appropriated for the needs of contemporary discourse. His work is used to contribute an Islamic element in the construction of an authentic postmodern perspective. The contemporary reception of Mullā Șadrā in Urdu is based on these two pillars: the scholastic traditions and the (post-)modernist, literary engagements with philosophy. Furthermore, because the intellectual classes who engage in the

(Lahore: Sang-e Meel, 2007); Khudā Falsafiyoñ kī Nazar Meñ (Lahore: Sang-e Meel, 2008); Falsafah-e Vahdat-e Vujūd (Lahore: Sang-e Meel, 2008); Fikriyāt-e Iqbāl (Lahore: Sang-e Meel, 2010); Rūh Kyā Hai? (Lahore: Sang-e Meel, 2011); Maqālāt-e Falsafah (Lahore: Sang-e Meel, 2011); Falsafah Kyā Hai? (Lahore: Sang-e Meel, 2013).

18 Naeem Ahmed, ed., Philosophy in Pakistan (Washington, DC: The Council for Research in Values and Philosophy, 1998).

19 Mehr Afshan Farooqi, Urdu Literary Culture: Vernacular Modernity in the Writing of Muhammad Hasan Askari (New York: Palgrave Macmillan, 2012), 11, 160-164, 190-193.

20 Nāșir 'Abbās Nayyar, Urdū Adab kì Tashkīl-e Jadīd: Nau Ābādiyātī aur Pas-e Nau-Ābādiyātī 'Ahd ke Urdū Adab ke Muțālāāt (Karachi: Oxford University Press, 2016). A Karachi University doctorate who later did a post-doctoral fellowship at Heidelberg, Nayyar is probably the leading postmodernist literary critic writing in Urdu today. 
postcolonial contexts of Urdu tend to be bilingual in English and Urdu (if not polylingual), the influence of English texts upon those Urdu compositions cannot be underestimated; not least the seminal works of Seyyed Hossein Nasr, Fazlur Rahman, and, more recently, Christian Jambet and Muhammad Kamal. ${ }^{21}$ The latter, who obtained his doctorate from Karachi University, is especially noteworthy in this regard. As we shall see, Iqbāl and these anglophone authors have had an important influence on the Urdu writings on Mullā Șadrā.

\section{Translation}

In the following, I look at four modalities of the reception of Mullā Șadrā. The first is translation and actually predates the English works. At least in principle, it could exhibit continuity with an older máqülàtī engagement with the Shirazi thinker, albeit with a modernist twist making Mullā Ṣadrā available and relevant. There are plenty of translations of philosophical texts which demonstrate this sort of engagement with the philosophical traditions. One thinks of the Lahore-based Salafì (ahl-e hadìs) thinker, researcher at the Institute of Islamic Culture and member of the Council of Islamic Ideology in Pakistan from 1962 until his death, Muhammad Hanîf Nadvī (1908-1987). Nadvi's translations include the theological doxography Maqālät al-Islämiyyìn (The Doctrines of Muslims; rendered as Musalmānoñ ke 'Aqā̉id o Afkār) of Abü'lḤasan al-Ash'arī (d. 936), Maqāṣid ul-Falāsifah (The Aims of the Philosophers; rendered as Qadìm Yūnānī Falsafah), al-Munqiż min al-Zalāl (Deliverance from Error; rendered as Sarguzasht-e Ġhazālü) and Tahäfut ul-Faläsifah (Incoherence of the Philosophers) of Abū Ḥāmid al-Ġhazālī (d. 1111) and Maktūbul-Madanī, being the second part of al-Tafhimāt al-Ilāhiyyah (Divine Explanations) of

21 Seyyed Hossein Nasr, Sadr al-Din Shirazi and his Transcendent Theosophy (Tehran: Imperial Iranian Institute of Philosophy, 1978); Fazlur Rahman, The Philosophy of Mullā Șadrā (Society for the Study of Islamic Philosophy and Science Series, Albany, NY: State University of New York Press, 1975); Christian Jambet, The Act of Being: The Philosophy of Revelation in Mulla Sadra, trans. Jeff Fort (New York: Zone Books, 2006); Muhammad Kamal, Mulla Sadra's Transcendent Philosophy (World Philosophies Series, Aldershot: Ashgate, 2006), and his From Essence to Being: The Philosophy of Mulla Sadra and Heidegger (London: Academy of Iranian Studies, 2010). Muhammad Kamal, of Iraqi Kurdish origin, is a Lecturer in Arabic and Islamic Studies at the University of Melbourne. He received his BA, MA and PhD in Philosophy from Karachi University (the last in 1988) and was an Assistant Professor of Philosophy at Karachi University 1985-1994. 
Shāh Valīullāh (d. 1762)..22 There are also Ghulam Husain Jalbani's translations of the works of Shāh Valīullāh in the 196os and 1970s through his Shah Waliyullah Academy in Karachi. In addition, more recently, the new Ibn 'Arabī Foundation in Lahore has published the translations of various works including the Fusūsus ul-Hikam (Ringstones of Wisdom) and al-Futühāt al-Makkiyyah (The Meccan Revelations) by Abrār Ahmmad Shāhī. 23

The work that is relevant here is the Urdu translation of the first journey on the metaphysics from al-Hikmah al-Muta'äliyah fi-l-Asfär al-Aqliyyah al-Arba'ah (The Higher Philosophy of the Four Journeys of the Intellect) of Mullā Ṣadrā Shīrāzī by a team led by Sayyid Manāzirir Aḥsan Gīlānī (18921956). Mullā Șadrā's major work maps the different branches of philosophymetaphysics, theology, epistemology, psychology and so forth—onto the four journeys of the human rational soul "traveling" first to God then back to creation. It is the metaphysics of Mullā Șadra which was contested and debated in the years after him not least in North India from the eighteenth century. Gīlānī had studied the rational disciplines (máqūlāt) including logic and philosophy for seven years (1909-1916) with Sayyid Barakāt Aḥmad (d. 1347/1929),

22 Musalmānoñ ke 'Aqā̉id o Afkār: Maqālāt ul-Islāmiyyı̄n, 2 vols. (Lahore: Idārah-e Ṡaqāfat-e Islāmiyyah, 1970); Qadīm Yūnānī Falsafah: Imām Ġhazālì kī Ahamm Kitāb Maqāṣid ul-Falāsifah kā Urdū Tarjumah (Lahore: Idārah-e Șaqāfat-e Islāmiyah, 1959), Sarguzasht-e Ǵhazālì ya'nī Ǵhazālì kì al-Munqiż kā Tarjumah aur Mabsūṭ Muqaddimah (Lahore: Idārah-e Șaqāfat-e Islāmiyyah, 1969), Tahāfut ul-Falāsifah: Talḳị̄s o Tafhìm (Lahore: Idārah-e Śaqāfat-e Islāmiyah 1974), and Maktūb ul-Madanī (Lahore: Idārah-e Ṡaqāfat-e Islāmiyah, 1965). Nadvī was a prominent public theologian and prolific author writing a six-volume Qur'anic exegesis Sirāj ul-Bayān published in 1950 and the following works introducing key genres of writing and intellectuals: Muțāla'ah-e Qur'ān (Lahore: Idārah-e Ṣaqāfat-e Islāmiyah, 1978); Muțāla'ah-e Hadīs (Lahore: Idārah-e Śaqāfat-e Islāmiyyah, 1979); Mas'alah-e Ijtihād (Lahore: Idārah-e Ṡaqāfat-e Islāmiyah, 1952); Asāsiyāt-e Islām (Lahore: Idārah-e Ṡaqāfat-e Islāmiyah, 1973); Chihrah-e Nubuvvat Qur'ān ke Āyinnih Meñ (Lahore: 'Ilm o 'Irfān Publishers, 1999); Afkār-e Ǵhazālı̀ (Lahore: Idārah-e Ṡaqāfat-e Islāmiyah, 1966); Ta lìmāt-e Ġhazālī (Lahore: Idārah-e Ṡaqāfat-e Islāmiyah, 1962); Afkār-e Ibn-e Khaldūn (Lahore: Idārah-e Ṡaqāfat-e Islāmiyah, 1995); al-Fihrist-e Ibn-e Nadīm (Lahore: Idārah-e Ṡaqāfat-e Islāmiyah, 1969); Aqlìyyāt-e Ibn-e Taimiyyah: Manțiq, Ilm-e Kalām aur Falsafah se Muta'alliq Allāmah ke Tanqīdī Mabāhnis kì Tauzịh o Tanqīh (Lahore: Idārah-e Ṡaqāfat-e Islāmiyah, 1965).

On Nadvī, see his obituary, Islamic Studies 26 no. 4 (1987), 395-396; Muhammad Qasim Zaman, Islam in Pakistan: A History (Princeton: Princeton University Press, 2018), 100-103, 203-204, 269.

23 Shaiḳh-e Akbar Muhyī ud-Dīn Muhammad Ibn ul-'Arabī, Fuṣuṣ̣ ul-Hikam o Ḳhuṣūṣ alKalim, ed. 'Abd ul-'Azīz Sulțān ul-Mansūb, trans. Abrār Aḥmad Shāhī (Lahore: Ibn ulArabi Foundation, 2015), and al-Futūḥāt al-Makkiyyah, ed. 'Abd ul-'Azīz Sulțān ul-Mansūb, trans. Abrār Aḥmad Shāhī (Lahore: Ibn ul-Arabi Foundation, 2016-) of which two volumes of a projected 37 have appeared. 
scion of the "school of Khairābād" at the Madrasah-e Khalīiyyah in Tonk in Rajasthan and, later, a luminary at the seminary in Deoband. ${ }^{24}$ In Tonk, he had studied all the works of the rational disciplines curriculum starting with the İsāğhūjī of Asīir ud-Dīn al-Abharī (d. 1263), al-Shams ul-Bäzig̀hah of Maḥmūd Jaunpūrī (d. 1654), the Șadrā (Sharh al-Hidāyah, Mullā Ṣadrās commentary on Abharìs Hidāyat al-Hikmah) all the way through to Faḳhr ud-Dīn Rāzì (d. 1210) and Nașîr ud-Dīn Țūsìs (d. 1274) commentaries on al-Ishārāt va-l-Tanbihät (Pointers and Reminders) of Avicenna (d. 1037) and al-Ufuq al-Mubìn of Mīr Dāmād (d. 1631). ${ }^{25}$ Later, he was appointed to the faculty of theology at Osmania University, where he became the Dean of Faculty. It was at Osmania he was commissioned by the university to translate the work of Mullā Șadrā. ${ }^{26}$

Two parts of volume one on metaphysics were published in 1941 and apparently the second journey (on the natural philosophy) was translated, but was not, to my knowledge, published. ${ }^{27}$ The famous Islamist thinker Abu-l-Ala Maududi (1903-1979) was also based at the translation bureau at Osmania and claims, in 1932, to have been involved in the translation of a work that he describes as "the most difficult Arabic text in philosophy," although the published

24 Sayyid Manāẓir Aḥsan Gīlānī, Ihạațah-e Dār ul-'Ulūm Deoband meñ Bīte Hu’e Din (Deoband: Maktabah-e Tayyibah, 1995), 21-25; Zafīr ud-Dīn Miftāhīi, Hayāt-e Maulānā Gülānì (Karachi: Majlis-e Nashriyyāt-e Islām, 1994), 39-49; Abū Salmān Shāhjahānpūrī, Maulānā Sayyid Manāz̧ir Ahsan Gülānī: Shaḳhșiyat aur Savāniḥ (Delhi: Anjuman-e taraqqī-e Urdu, 2002), 7-8; Sayyid Maḥbūb ul-Ḥasan Rizvī, Tārīkh-e Dār ul-Ulüm-e Deoband, trans. Murtaza Husain Qureshi as The History of the Dar al-uloom Deoband (Deoband: Idārah-e Ihtimām, Dār ul-'ulūm Deoband, 1981), 2:84-86. On Sayyid Barakāt Aḥmad as successor to 'Abd ul-Ḥaqq Ḳhairābādī (d. 1899) and the Ḳhairābādī tradition, see Mahmūù Barakātī, Maulānā Sayyid Barakāt Aḥmad: Sīrat aur 'Ulūm (Karachi: Barakāt Academy, 1993).

25 This last text seems to have been particularly of interest - for the intersections with logic and semantics and not just for its metaphysics—in the "Khairābād school" and not so much among the Farangī-Mahall scholars of the Dars-e Niz̄āmī. See Sajjad Rizvi, "Mīr Dāmād in India: Islamic Philosophical Traditions and the Problem of Creation," Journal of the American Oriental Society 131 (2011), 21-22; Asad Q. Ahmed, "Logic in the Khayrabad School in India," in Law and Tradition in Classical Islamic Thought: Studies in Honor of Professor Hossein Modarressi, ed. Michael Cook et al. (New York: Palgrave Macmillan, 2013), 227-243.

26 Asfār-e Arba'ah, trans. Sayyid Manāzirir Ahssan Gīlānī, 1 vol., 2 parts (Hyderabad: Dār ul-Tibā'ah, Osmania University, 1941). On the role of Osmania University's translation bureau in fostering a sense of Muslim belonging, an educational project, and developing an Urdu literature capable of surviving and thriving in the modern world, see Kavita Datla, The Language of Secular Islam: Urdu Nationalism and Colonial India (Honolulu: University of Hawaii Press, 2013), especially 56-81.

27 The extant translation therefore covers the equivalent of the first volume (of four) of the Tehran Rajab 1282/November 1865 lithograph of the Asfär. 
work does not mention his name. ${ }^{28}$ Masudul Hasan reports that the work of translating the whole text into 3,500 pages took eight months in 1932. No mention is made of Gīlāni as the project manager or editor. The two parts of volume one on the first journey are available. The first part covers the first five sections (marāhil) of the first journey containing 686 pages in the translation with a detailed table of contents. The front cover mentions the date of $1360 \mathrm{H}$ or 1941 and names the translator as Sayyid Manāzir Aḥsan Gīlānī, the "director of the religious studies department" at Osmania University. The second part covers the second five sections of the first journey and comprises 1072 pages of translation. On the final page, the colophon of the manuscript used is reproduced in translation dated Jumāda I 1222/July 1807; this is the date of the Iṣfahān manuscript produced by Mīrzā Ḥasan Fānī-e Zunūzì and is used as the basis for the 1282/1865 Tehran lithograph. The date of the completion of the translation of the first journey is given: 10 Jumāda II 1359/July 1940, which is a date somewhat later than the one given by Maududi. ${ }^{29}$ There is no evidence that any further volumes were published. Given the absence of any preface explaining why the translation was undertaken, when it was commissioned or undertaken, and whether by a team or an individual, it is entirely possible that Maududi and others were involved in an early draft which was then reworked and edited by Gīlānī in a process that was completed in 1940 prior to publication.

The translation itself is indicative of many works rendered into Urdu. While there is little doubt of the skill of Gīlāni as an Arabist, the work is more of a paraphrase than a translation. It makes a common choice-evident in the Persian translations of Javād Muṣlih (Professor of Philosphy at Tehran University and the first major, albeit partial, translator of the Asfär in the 1940s) and Muhạmmad Ḳhvājavī (a prolific editor and translator who completed a multivolume translation in the 1990s) - not to translate technical terms but to retain them in Arabic such that it is only the verbal and other syntactical features

28 Sayyid Abū'l-A'lā Maudūdī, "Ḳhvud-navisht," in Maulānā Maudūdī: Apnī aur Dūsroñ kī Nazar Meñ, ed. Muḥammad Yūsuf Bhuțțoh (Lahore: Idārah-e Ma'ārif-e Islāmī, 1984), 36; Masudul Hasan, Sayyid Abul-A'ala Maududi and His Thought (Lahore: Islamic Publications, 1984), 1:75; 'Abd ul-Ġhanī Fārūqī, "Hayāt-e Jāvīdān," Haft-rozah-e Zindagī, Maudūdī Number (September 29-October 5, 1989), 26; Seyyed Vali Reza Nasr, Mawdudi and the Making of Islamic Revivalism (New York: Oxford University Press, 1996), 24, 149. Another recent reprinting of the translation that just came to my attention suggests that of the two parts published, Gīlānī was responsible for part 1 and Mawdūdī for part 2, but there is no new evidence adduced for this.

29 Asfār-e Arba'ah, trans. Sayyid Manāẓir Aḥsan Gīlānī (Hyderabad: Dār ul-Ṭibā‘ah, Osmania University, 1941) 1:1757. 
and structures that are translated. ${ }^{30}$ The lexicon of metaphysical terms remains in Arabic—vujūd for existence (not hastī or even honā), mähiyat for essence (not chistì), 'illat for cause, 'ilm for knowledge (not shinākht or shināsa $\bar{\imath} \overline{\text { ) }}$ and so forth. ${ }^{31}$ One wonders how many readers-not least in the twenty-first century—-would understand this sentence: insān do muḳhtalif aḳhlāț o 'anāsirir kā majūnn-e murakkab hai (the human is a "paste" composed of two distinct elements and temperaments). The choice of the Asfär itself is interesting because the ma'qülät tradition was far more familiar with the commentary on the Hidayat ul-Hikmah. While there is a large number of manuscripts of the latter as well as lithograph printings and popular offset printing for use in the madrasas, there are relatively few copies of the Asfär extant in South Asian libraries. Akbar Subūt's book on Mullā Șadrā in South Asia also points to the rare occasions when specialists wrote on the Asfär and demonstrated a knowledge of it, as well as showing how often the text was brought to bear on issues in the Sharh ul-Hidayah. ${ }^{32} \mathrm{~A}$ rare exception is the incomplete commentary on the Shi'i supplication Du'ẩ ul-Mashlūl by Sayyid Murtazāa Nawnehravī (d. 1917) entitled Mirrāj al- Uqūl (Ascension of the Intellects) which extensively cites and discusses the ontology of Mullā Șadrā, arguments for the existence of God, and divine attributes. ${ }^{33}$

The Osmania translation has recently been reprinted in Karachi in 2015 by an organization called Book Time based in Urdu Bazaar. It is not just an offset printing of the original Hyderabad edition, but has been newly typeset and published with a short, two-page introduction to Mullā Șadrā. For no obvious reason, it reproduces the colophon of part two of volume one from the Hyderabad printing but with the dates omitted, perhaps almost as if the origins of the translation in the Osmania bureau were being eradicated. Interestingly, the publisher on the flysheet makes this comment:

The aim of Book Time is to publish high quality research. The books published under our auspices are not intended to hurt anyone's feelings or offend. Rather they are intended to change and revive the book market.

30 Javād Muṣliḥ, Falsafah-e 'Ālì yā Hikmat-e Șadr ul-Muta’allihīn, 3 vols. (Tehran: Tehran University Press, 1953-54), and Muhammad Ḳhvājavī, Tarjumah-e Asfār-e Arba'ah, 10 vols. (Tehran: Intishārāt-e mawlā, 1998).

31 Various other words in Urdu whose meaning is dependent on context are derived from Arabic—sabab, bā is̀, vajah, for example.

32 Subūt, Fülsūf-e Shīrāz dar Hind (Tehran: Intishārāt-e Hirmis, 2001), 22, 77, 245, 289, 309.

33 The text that claims to be the first of five volumes was published in 1916 for the first time. A digitally enhanced edition based on a copy in the library of the Raja of Mahmudabad was published in London by the Shi'ah Institute in 2017. 
Whenever an author writes a work, it represents his own research and thoughts which need not reflect nor agree with either your thoughts or beliefs or even ours and our institution's. Our intention is merely to publish works of quality research. ${ }^{34}$

Unfortunately, the preface tells us nothing about the translation nor does it mention the South Asian context or why this has been reprinted. Within the apologetic presentation, the publisher prefaces a short introduction to Mullā Șadrā which explains his "peerless" contribution to Islamic philosophy. His thought is said to consider knowledge in a holistic and transformative manner; holistic because it reconciles reason, revelation, and intuition transgressing the oppositions of the modernist turn; transformative because it locates knowledge within the connection between will, action, and the expression of the self. ${ }^{35}$

It is also clear that this preface is written by someone with a rather perfunctory knowledge of Mullā Șadrā's thought and legacy; there are significant errors, not least in the simple rendition of the names of his nineteenth-century commentators-for example, Zunūzī not Nunūzī, Nūrī not Ghaurī, Aḥsāì not Aḥsạà'î. It is similarly not accurate to say that Mullā Ṣadrā suffered a decline before his nineteenth-century revival; rather it took some time for his approaches and arguments to supersede those of Avicenna in philosophy. It was through the efforts of those nineteenth-century commentators that it became the dominant school of philosophy. The translation itself-a shortcoming, of course, of the original effort in Hyderabad - is more of a paraphrastic nature than a precise rendition of the Arabic. Perhaps the main reason, alongside the use of technical Arabic terminology, is simply that a very literal translation would be unreadable and confusing; although again, to cite another example, this may already be the case. In the first section on the notion of first philosophy foundational to any type of human scientific inquiry, al-ma'ārif allatì yuhtāju ilāihā al-insānu fì jamì al-ulūm is rendered as un ma'lūmāt aur ma'ārif ke bayan meñ hai jin kì țaraf insān dunyā ke tamām 'ulūm o funūn ke samajhne meñ muhtāj hai (in description of the information and sciences on which humans depend in understanding all the sciences and arts of the world). The translations thus tend to reorganise the Arabic (no doubt partly due to the syntactical differences between a Semitic and an Indo-European language) as well as paraphrase and gloss the original (sometimes by adding synonyms

\footnotetext{
34 Șadr ud-Dīn Shīrāzī, Asfār-e Arba'ah: Falsafah-e Mullā Șadrā (Karachi: Book Time, 2015), flysheet.

35 Șadr ud-Dīn Shīrāzī, 5-6.
} 
for emphasis). ${ }^{36}$ To take another example, in the second chapter of the first section, "the concept of existence is predicated of its individuals by modulation and not by univocity" is rendered vujūd kā mafhüm mushtarak hai aur apne tamām mā tahat umūr par yih yaksānī aur tavātư' ke sāth nahīn balkih tashkikki taur par mahmūl hai (the concept of existence is shared among its instances not by univocity or synonymy but by a modulated predication). Here a more accessible Urdu equivalent is added for univocity but not for modulation.

Fundamentally, the practice of the translation-and its reprint-begs the question of the amount of readership for the work. However, the simple fact that it exists and is available on the book market-in a quantity of copies far exceeding the original Hyderabad printing - will lead to an assessment of its impact and influence in the future. Will it be of scholastic or antiquarian interest, or revive a serious engagement with the ma'qūlāt tradition?

\section{Triumphalism}

The second modality of the reception of Mullā Șadrā's is the triumphalist championing of his thought as "relevant" for the contemporary world, particularly amongst the intellectual classes and literary culture of Pakistan. The work best representing this is Sayyid Mashkūr Husain with the takhalluș (pen-name) "Yād" (1925-2017) and his work on the "practicability" of Mullā Sadrā's philosophy, which was first published in 1998 and then reprinted in 2009 under a new title. ${ }^{37}$ The reprint is clearly aimed at readers of Yād because the back cover presents the front covers of his various books. The front cover of the reprint reproduces the "artist's impression" of Mullā Șadrā that has been used by the Sadra Islamic Philosophy Research Institute in Tehran since the mid-199os and gives the title "the philosophy of being of the great Muslim thinker Mullā Sadrā." The contents of the 2009 printing are identical to the 1998 one except for one small difference: the bibliography of sources consulted is dropped. Both printings have the same table of contents and both are not supported by any indices. ${ }^{38}$

\footnotetext{
36 Șadr ud-Dīn Shīrāzī, Asfār-e Arba'ah, 15 .

37 Sayyid Mashkūr Ḥusain, "Yād," Mullā Șadrā kā Qābil-e 'Amal Falsafah (Lahore: al-Razzāq Publishers, 1998), and 'Azīm Muslim Mufakkir Mullā Șadrā kā Falsafah-e Vujūd (Lahore: Klāsīk, 2009).

38 The absence of indices in Urdu prose publications is rather common and deeply regrettable.
} 
Yād was a published poet, littérateur, and Professor of Urdu at Government College Lahore; he wrote extensively on the history of Urdu poetry. ${ }^{39}$ Within the context of his work on literature, intellectual contexts, and influences, he presents this essay on the relevance of Mullā Șadrā, which he locates in a comparison with Marx. Given the prominence of Marx among the leftleaning Pakistani intelligentsia, Yād's appropriation of Mullā Șadrā fits a broad response to the political and materialist intellectual challenge of Marxism. This mode of combating leftist thought became popular (partly through government support) in the 1980 os. As a poet and literary critic writing on stylistics, especially the prose essay, Yād was known for his inclination to philosophy and the use of philosophical argument in literary analysis. According to Yād, both Marx and Mullā Șadrā were frustrated by the lack of a definitive philosophy and the plethora of speculatively futile metaphysics; however, their responses were different: the cacophony of philosophies led Marx to reject metaphysics and reduce philosophical inquiry to the material, while Mullā Șadrā recognized that the material was meaningless without the transcendent and the metaphysical —it was the higher intelligible world that gave meaning to this material world, but it was in search of a philosopher best able to explain it. ${ }^{40}$ Hence what is practicable is that for a Pakistani society which does not want to restrict its conception of existence to the material and the ephemeral, Mullā Șadrā provides a philosophy of being that explains the metaphysical foundations of our phenomenal reality without the need for the "descent of angels" to explain this to us. ${ }^{41}$ It is the existential focus of Mullā Șadrā’s thought and his

39 Apart from his collections of poetry, he was best known for his work on the marsiyah poet Mīr Anīs (d. 1874) and on the poetry of Ġhālib (d. 1869); see Muțăla'ah-e Anīs ke Nāzuk Marāḥil (Lahore: Klāsīk, 2002), Mīr Anīs kī Shāiriānah Bașīrat (Lahore: Klāsīk, 2003), Ġhālib Būțīqā: Ash'ār-e Ġhālib kì Tafhìm (Lahore: Educational Publishing House, 2003), and Ġhālib kā Żauq-e Ilāhiyyāt: Raushan Ḳhayālē aur Hurriyyat-e Fikr ke Havāle Se (Lahore: Zulfiqār 'Alī Shayḳh, 1999). He was also one of the pioneers writing on the essay as a literary genre in Urdu; see Jauhar-e Inshāìyyah (Lahore: Maktabah-e Urdū Digest, 1978) and Mumkināt-e Inshā̉iyyah: Inshāìyyah ke Mizāj aur Imkānāt par Bunyādī Mabāhis (Lahore: Polymer Publications, 1983). His memoir of partition, $\bar{A} z \bar{a} \bar{d} \bar{\imath} k e$ Chirägh , is well known and constantly in print, most recently from Karwan-e Ilm Foundation in Lahore in 2008 (first published in 1971). I had the privilege of meeting him during the Mullā Șadrā Congress in Tehran in May 1999 when he graciously gifted me a copy of his book on Mullā Ṣadrā.

The dominance of Marxism and leftist thought among Pakistani intellectuals is well established, especially centred on the work of Sayyid Sibț-e Hasan (1916-1986); see, for example, his popular Mūsā se Mārks Tak (Karachi: Maktabah-e Dāniyāl, 1988). For the relevance of Marxism, see Kamran Asdar Ali, Communism in Pakistan: Politics and Class Activism, 1947-1972 (London: I.B. Tauris, 2015).

Yād, Mullā Șadrā kā Qābil-e 'Amal Falsafah (Lahore: al-Razzāq Publishers, 1998), 9. 
philosophical method that is relevant to our age. ${ }^{42}$ Yād highlights one methodological point and two key features of Mullā Șadrā's philosophy. On the former, he mentions that Mullā Ṣadrā presents a philosophy grounded and illuminated by the "light of faith" and a sincere spirituality. ${ }^{43}$ The religious and spiritualand hence practical—commitments of Mullā Șadrā are critical. The problem is that he suggests this makes his thought practicable for the average person (nārmal insān)—ignoring the philosopher's elitism. The potential aptitude for a person to perfect their rational soul is universal, but the vast majority of humans fail to do so and, besides, that would require seeking out a sage under whose guidance one would have to train. Still, the emphasis on religious commitment is an important insight and indeed a potential corrective for most who might be influenced by the analytic tradition, but, unfortunately, Yâd does not substantiate it.

The two key features Yâd highlights are the focus upon the soul as the true human self that in its perfect form is immaterial and hence transcends both the material and ephemeral, and the importance of the notion of being as a simple reality that is paradoxically both one and many. ${ }^{44}$ Methodologically, Yād is influenced by the Corbin-Nasr approach to Mullā Șadrā as a Sufi esotericist enamoured of the way of paradoxes - and yet the actual analysis of existence follows Rahman's presentation. ${ }^{45}$

After brief chapters on Mullā Șadrā's life and works and a summary of his contribution, the bulk of the book presents the connected tripartite doctrine of existence, namely that (1) existence is an ontological foundation in extramental reality whereas essences are mental constructions through which we make sense of reality, (2) existence is a singular reality graded and modulated in levels of intensity, and (3) motion and flux is the basic dynamic of existence. ${ }^{46} \mathrm{~A}$ very short chapter on Mullā Șadrā's originality merely mentions later commentators who stress that feature of his thought, but adduces no evidence. The chapter on time mentions the point made by a number of modern interpreters, including Rahman, that time for Mullā Șadrā is relative and unreal. Remaining chapters then examine the nature of God and the nature of human knowledge without explicitly examining either the infallibilist epistemology of presential knowledge or the identity thesis whereby knowledge is the union of the intellecting subject and object that reverts back to Aristotle's

\footnotetext{
42 Yād, Mullā Șadrā, 10.

43 Yād, Mullā Ṣadrā, 10-11.

44 Yād, Mullā Șadrā, 13-19, 28-32.

45 Yād, Mullā Șadrā, 20-23.

46 Yād, Mullā Ṣadrā, 51-10o.
} 
Metaphysics book Lambda. Before that, we have two chapters on his conception of philosophy and on the Asfär; both are highly influenced by Perennialist thought and likely should have come at the beginning. ${ }^{47}$ The final two chapters deal with the eschatology of life after death and focus on Mullā Șadrā's argument about the world of the afterlife and the imagination of the soul recreating the body. ${ }^{48} \mathrm{He}$ has an important insight here: because Mullā Ṣadrā has two concepts of the "world of images," one can easily be deceived into assuming that the afterlife is purely imaginal. In this life, the imaginal is the intermediate realm of ideas and images that lies between the higher intelligible and the lower sensible worlds, but with respect to our phenomenal reality is not "real." However, in the afterlife, the imaginal is productively real and full of life and the means whereby what is internalized in the mind and in the world of images is then externalized into the realities of the eschaton.

From the contents of the work (and here I will focus on the original printing) and the appended bibliography, it seems to be clear that Yâd did not rely on the Arabic works of Mullā Șadrā or even their Persian or Urdu translations. He notes that he "saw" the works of the philosopher in the personal library of the famous Shi'i Urdu ḳhațīb 'Allāmah Țâlib Jauharī in Karachi. It is also evident that Yãd used four types of sources: introductory secondary works in English on Mullā Șadrā, most important among them being the monograph of the Pakistani modernist thinker Fazlur Rahman (1919-1988); ${ }^{49}$ general histories of Islamic philosophy including Iqbāl's famous doctoral dissertation and the history edited and published in 1966 by the eminent Pakistani philosopher and founder of the Pakistan Philosophical Association Mian Mohamed Sharif $\left(1893^{-1965)}\right)^{50}$ the works of the Perennialist school such as Seyyed Hossein Nasr, Martin Lings, and William Chittick, who have done much to promote

47 Yād, Mullā Ṣadrā, 106-123.

48 Yād, Mullā Ṣadrā, 149-163.

49 There are three main works in this category: Fazlur Rahman, The Philosophy of Mullā Șadrā (Albany: State University of New York Press, 1975); Seyyed Hossein Nasr, Sadr al-Din alShirazi and his Transcendent Theosophy (Tehran: Imperial Iranian Academy of Philosophy, 1978); James W. Morris, The Wisdom of the Throne (Princeton: Princeton University Press, 1981), which contains a translation of Mullā Șadrā's Arabic text al-Hikmah al-Arshiyyah.

50 Two main collections: M.M. Sharif, ed., History of Muslim Philosophy, 2 vols. (Wiesbaden: Otto Harrassowitz, 1963-66), which contained the first introduction to Mullā Șadrā in English by Nasr, and S.H. Nasr and Oliver Leaman, eds., History of Islamic Philosophy (London: Routledge, 1996), which has chapters on Mullā Șadrā (Hossein Ziai, "Mullā Șadrā: Life and Works," 2:635-642, and Seyyed Hossein Nasr, "Mullā Șadrā: his teachings," 2:643-662) and other philosophers before and after him. And Iqbāl's doctoral dissertation (Yād refers to it as his maqālah), The Development of Metaphysics in Persia (London: Luzac \& Co, 1908), reprinted in Pakistan many times. 
the study of Mullā Ṣadrā in English since the 196os, presenting him as a "Suf" whose thought could be reduced to that of Ibn-e 'Arabī; 51 and works by modern philosophers such as Heidegger, Sartre, and Derrida to provide a comparative framework. Interestingly, there are no works from the Anglo-American analytic tradition, betraying a sense held by Nasr and others that there can be no realistic dialogue between Mullā Ṣadrā and the analytic tradition, any dialogue should take place with continental thought. ${ }^{52} \mathrm{He}$ only includes two works in Urdu: Falsafe ke Jadīd Nazariyāt (Modern Theories in Philosophy) of Qazi Qaiser ul-Islam (1934-1998), ${ }^{53}$ and a translation of the classic, perhaps oldest, European history of Islamic philosophy by the Dutch orientalist Tjitze J. der Boer (1866-1942). ${ }^{54}$ As such, this reveals a synthetic work aimed at explaining Mullā Șadrā’s mysticizing metaphysics to thinkers and readers like

$5^{1}$ Works cited include William Chittick's monographs on Ibn 'Arabī and on Sufi's pluralism: The Sufi Path of Knowledge (Albany: State University of New York Press, 1989) and Imaginal Worlds (Albany: State University of New York Press, 1994); René Guénon's The Reign of Quantity and the Signs of the Time, trans. Walter James, Baron Northbourne (London: Luzac \& Co., 1953) and The Multiple States of Being, trans. Joscelyn Godwin (London: Larson Publications, 1984); and Titus Burckhardt's abridged translation of the Wisdom of the Prophets (Fușuṣ al-ḥikam) of Ibn 'Arabī translated into French by Angela Culme-Seymour. Perennialist works are reprinted by the Suhail Academy in Lahore run by the Perennialist Muhammad Suheyl Umar. On these Muslim Perennialists (or traditionalists), see Mark Sedgwick, Against the Modern World: Traditionalism and the Secret Intellectual History of the Twentieth Century (New York: Oxford University Press, 2004), 39-53, 147-177, and Western Sufism: from the 'Abbasids to the New Age (New York: Oxford University Press, 2017), 172-176, 202-207.

$5^{2}$ The standard "great works" in this category include Heidegger's Being and Time, Jean-Paul Sartre's existentialist manifesto Being and Nothing, and Jacques Derrida's of Grammatology. On Nasr's rejection of the analytic tradition-no doubt influenced by Henry Corbin-see the various contributions and responses in The Library of Living Philosophers: The Philosophy of Seyyed Hossein Nasr, ed. Lewis Hahn et al. (Chicago: Open Court, 2001).

53 Qāẓ̄i Qaișar ul-Islām was not a professional philosopher but an autodidact best known for three works: Falsafe ke Jadìd Nazariyāt, Falsafe ke Bunyādī Masā’il, and Tärīkh-e Falsafah-e Mağhrib. Two volumes were posthumously published by the Idārah-e Yādgār-e Ġhālib in Karachi, edited by his widow Mahjabeen: Falsafiyānah Mukālame (Philosophical Exchanges), and Jadìd Falsafiyānah Afkār (New Philosophical Thoughts).

54 De Boer, Geschichte der Philosophie im Islam (Stuttgart: Franz Frommans, 1901), and then translated by Edward R. Jones as The History of Philosophy in Islam (London: Luzac \& Co., 1903). De Boer notes that he is drawing on earlier work by Dieterici, Renan, Goldziher, Munk and Carra de Vaux but that his work is the first attempt to produce a full history that includes a discussion of philosophy within Arabic literature while also discussing mystical ideas and kalām scholastic theology alongside the Aristotelian and Neoplatonic traditions in Arabic. Later Islamic philosophy in the East including Mullā Ṣadrā are not discussed-they first appeared in European languages with the monographs of Max Horten (1874-1945) based on the 1865 Tehran lithograph of the Asfär which includes the glosses of Mullā Ṣadrā’s follower Hādī Sabzavārī (d. 1873) whom Horten incorrectly 
himself engaging with literary criticism, modern European philosophy, and, especially, leftist thought. It is a highly competent exposition of the thought of Mulla Șadrā based on the work of Rahman - and shares the paradoxes, ambiguities, and mistakes of that work. There is no attempt to link the study of Mullā Șadrā to the intellectual history of Muslims in South Asia (or the Dars-e $N i z \bar{a} m \bar{\imath}$ for that matter) and hence he is not championed in search of authenticity to a particular tradition. There is no conclusion and the fundamental postulation of the title is not established. In what way is Mullā Șadrā's philosophy practicable today in Pakistan for Yād's readers? In that sense, the championing of his thought remains merely rhetorical; Yād has not substantiated his opening claims.

\section{3}

\section{Moderate Critique}

The third modality of reception is a critical engagement of Mullā Șadrā aimed at a learned readership including those trained in British analytic philosophy - the dominant mode of professional philosophy in Pakistani academia. This mode is evident in Ḳhiẓr Yāsīn's critical appraisal of Mullā Ṣadrā's philosophy of being in the form of the publication of his doctoral dissertation supervised at the University of Punjab by Professor Naeem Ahmad (b. 1946). ${ }^{55}$ He dedicates the work to Burhan Ahmad Faruqi (1906-1995), whose career was primarily a defence and promotion of the thought of the Mughal Sufi Ahmad Sirhindì (1564-1624) ${ }^{56}$ Yāsīn works at the Iqbal Academy. From the bibliography, as well as the text, it is clear that his access to the works of Mullā Ṣadrā, Ibn ul-'Arabī, and others is mediated by Persian translations although he also refers to the original Arabic texts, and that he is familiar with anglophone writings on the philosophers up to the 199os. He also cites and engages the analytic tradition as well as elements of phenomenology (Husserl) and the philosophy of mysticism (Stace, James, and others). After thanking his supervisor and colleagues in his acknowledgements, Yāsīn notes that it is rare for a philosophy doctorate to be published as people tend to find it very difficult or assume that philosophy is opposed to religion, more so if the work defines itself as a critique since most people take critique to be negative. ${ }^{57}$ However,

renders as "Bazwārī" (Die Gottesbeweise bei Schirāzī [Bonn: Friedrich Cohen Verlag, 1912], and Das philosophische System von Schirāzī [Strassburg: Trübner Verlag, 1913]).

55 Ḳhiẓr Yāsīn, Mullā Ṣadrā kā Tașavvur-e Vujūd: Ek Falsafiyānah Tanqīd (Lahore: Kitāb Mahall, 2017).

56 Burhan Ahmad Faruqi, The Mujaddid's Conception of Tawhid (Lahore: Shaikh Muhammad Ashraf, 1979).

Yāsīn, Mullā Șadrā, 7-8. 
critique is essential to philosophy. The abstract then makes the subject of inquiry clear-in many ways it is a study of modulation of existence. ${ }^{58}$ Existence is a mental concept that is homonymously predicated of instances (the notion of ishtirāk-e ma'navì); predication still has a focal sense hence it is a modulated concept - the concept is merely mentally posited and not a constituent of the individuality of the thing. Extra-mental existence, however, is the very thing that exists, and is arranged in a modulated ontology in which each "intensity" of existence presents itself as a dyad of existence and essence. In his introduction on Mullā Sadrā, which is broadly derivative, he signals that his analysis draws primarily on Rahman, Nasr, and Morris. ${ }^{59}$

In the introduction to the subject, he begins with a rather general reflection on philosophy as a search for singular origins - what is the basic stuff of reality and where do we come from? The Presocratics tended to ask this question, as did religious traditions. ${ }^{60}$ Mullā Șadrā's answer is simple-everything is existence and comes from existence (vujüd) ${ }^{61}$ The core of the thesis then investigates this in four stages: the concept of existence; that existence is a predicate and has reference in extra-mental reality; that existence is modulated; and, finally, the relationship between existence and essences. Unfortunately, there is no conclusion that ties things together. A bibliography is appended to illuminate the author's path to the subject, but as ever with Urdu publishing, no index.

Each chapter is well-structured with sections and a final summary ( $m \bar{a}$ hasal). The first chapter traces the concept of the semantic idea of existence and its predication by modulation from Avicenna through to Mullā Ṣadrā and cites original texts to illustrate the points. The main thrust is to distinguish between the concept and reality of existence and to justify the modulated nature of the concept (on which he attempts a critique which was already considered in the Avicennian tradition). ${ }^{62}$ The second chapter on the fact that existence is all there is and that it is a real predicate is presented through ten "witnesses" from the work of Mullā Șadrā. This is what the tradition calls the "ontological priority" or the "actuality" of existence (așālat ul-vujūd, 'ainiyyat ul-vujūd). Here he injects three objections that draw on Fazlur Rahman. First, if existence is considered to be ontologically prior and singular, but it also manifests itself in plurality, is there not a tension between monism and pluralism? Second,

\footnotetext{
$5^{8}$ Yāsīn, Mullā Ṣadrāa, 10-13.

59 Yāsīn, Mullā Ṣadrā, 20-21.

6o Yāsīn, Mullā Ṣadrā, 23-27.

61 Yāsīn, Mullā Ṣadrā, 28.

62 Yāsīn, Mullā Ṣadrāa, 75-78.
} 
is Mullā Șadrā's metaphysics not circular, since the notion that existence is prior is not actually argued, but based on the self-evident nature of existence? Third, there is a tension between whether essences have any reality whatsoever or whether they are the way in which an intensity of existence presents itself. ${ }^{63}$ These are not new objections and if the author had considered the tradition he would have encountered the responses that make clear that there is a certain coherence to the metaphysics as a system.

The third chapter moves onto a more detailed examination of modulation of existence (tashkikul-vujüd). He objects that it is odd to suggest that the secondary intelligible that is the concept of existence can be predicated by modulation since it does not have individuals as such; however, that is precisely how modulation as a semantic concept works in the Avicennian tradition. Second, he seems to think that the only way existence can be both a principle of commonality and difference is if one rethinks the Aristotelian categories and does not differentiate between quantity and quality. But the notion of intensity is another type of "more or less" and in effect the Aristotelian category theoryand hylemorphism, which considers entities to be dyads of form and matteris just not that important for Mullā Șadrā. It is also misleading to suggest that he thinks that non-existence, just like existence, is a modulated concept. It is not. If existence is a modulated pyramid or hierarchy of being, then the less intense degrees which are more contaminated and embodied forms of existence are not degrees of non-existence; they remain within the hierarchy of existence itself. Modulation to a large extent is the most objected concept in Mullā Șadrā's thought and there is more by way of objection that would have been possible.

The final chapter deals with the problem of the relationship between existence and essence. Do essences actually exist? Are essences the essential accidents of existence, rendering them the true subject of metaphysics? Any distinction between existence and essence presumes that the two sides of the binary have some reality. But the way in which Mullā Șadrā and others in his tradition solve this is through recourse to the notion of the different modalities and conditions relating to essence.

Yāsīn's work is the most serious engagement with Mullā Șadrā, but despite the references in the bibliography and elsewhere there is little attempt to bring his thought into a serious dialogue with either analytic or continental traditions. It would have been useful to have seen a conclusion which would summarize exactly where Yāsīn thinks Mullā Șadrā goes wrong and what his critique is. As far as it is clear, most of the objections and critiques seem to

63 Yāsīn, Mullā Ṣadrā, 109-110. 
come from the existing work of Rahman as well as those from the tradition of Iqbal. The objections also show how the divergence of the legacy of Mullā Sadrā, both the adoptive and the critical, is a major issue if one compares the South Asian reception to the Iranian one. Nevertheless, Yāsīn is writing as an insider within the academic circle of philosophy in Pakistan and hence addressing his (broadly favourable) critique to that particular audience, with an implicit call for that academy to embrace and teach Mullā Șadrā alongside other philosophers within the university curriculum.

The fourth and final modality within the contemporary reception of Mullā Sadrā is the analyticizing examination of a particular concept in his thought. This is Sayyid Nāșir Razā Zaidī's analysis of the proofs for the existence of God in the philosophy of Mullā Sadrā. ${ }^{64}$ The author is familiar with the Iranian secondary literature, including the seminarian work, and seems to be based in Karachi. Zaidī makes it clear in his introduction that there is a need for Muslims in South Asia to meet the intellectual challenge of the West through familiarity with their own philosophical traditions. ${ }^{65}$ Philosophy is central to human culture and expression and needs to be championed and embraced. Zaidi's conception of philosophy is an instrument of cultural struggle and conflict in which Iranian thinkers such as Mullā Șadrā and his modern commentators such as Sayyid Jalāl ud-Dīn Āshtiyānī (d. 2005), Seyyed Hossein Nasr, Mihdī Ḥāerē Yazdī (d. 1998), and Âyatullāh Javādī Âmulī are used to combat the threat of modernism, postmodernism, and other challenges to Islamic metaphysics and belief from western thought. ${ }^{66}$ Within this context, selecting the study of the proofs for the existence of God is an appropriate topic since in modern Iranian seminarian philosophy (of the school of Mullā Șadrā), the existence of God is both the ground for metaphysical inquiry and indeed the end of metaphysics as well. ${ }^{67}$

The work comprises six chapters. He begins with an introduction to Mullā Șadrā’s thought in general, which includes a consideration of his critics (Ziyā

64 Sayyid Nāṣir Razāā Zaidī, Dalā̉il-e Vujūd-e Bārī-Táălā Mullā Șadrā Shīrāzì kī Nazar Meñ (Islamabad: al-Baseera, 2006).

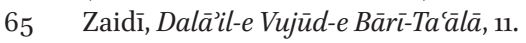

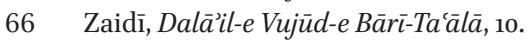

67 See Sajjad Rizvi and Ahab Bdaiwi, “Allāmah Țabāțabā’ī: Nihāyat al-hikmah", in The Oxford Handbook of Islamic Philosophy, ed. Khaled el-Rouayheb and Sabine Schmidtke (New York: Oxford University Press, 2016), 654-673. 
ud-Dīn Durrī and Șālihịi Māzandarānī) and the Persian and English secondary literature. It is clearly the best contextualising introduction to Mullā Șadrā available in Urdu. ${ }^{68}$ While acknowledging the "eclectic" and "synthetic" nature of Mullā Sadrā's thought and its reconciliation of Peripetatism and Illuminationism, Zaidī does point out the areas in which Mullā Ṣadrā diverges from these two schools. Some attempts to render concepts into English are misleading: he translates Ibn ul-Arabīs notion of khalq-e jadid as "creatio continua," but that is the term that the modern Christian traditions use to render occasionalism and it is clear from Ibn ul-Arabī's critique of the Ash'arī tradition that he was no occasionalist. ${ }^{69}$

Three chapters follow on different paths for proving the existence of God, drawing upon Mullā Ṣadrā's own classification as well as Nașīr ud-Dīn Ṭūsì's from his commentary on Avicenna: the proof from motion; the proof from creation; and the proof from contingency, which is Avicenna's famous proof. The first of these chapters begins with arguments from motion in ancient philosophy from Anaxagoras to Aristotle's "unmoved mover" bringing things from potentiality to actuality as their final and efficient cause. ${ }^{70}$ The chain of causes considered and the need for that chain of motive beings to culminate in the mover who is unmoved is usually predicated on the notion that infinite chains of beings_- "actual" infinites-do not obtain in ancient science. Zaidī presents the shortcomings of this mode of proving the existence of God from Avicenna through to Javādī Āmulī (without mentioning Averroes' defence), citing Aquinas' defence along the way. ${ }^{71}$ For Mullā Șadrā, the proof from motion is weak because it relies on a contingent notion and entity: motion only arises in contingency since it bears within it both the notion of potentiality and propensity. ${ }^{72}$ These cannot enter into the notion of God, who in this sense

68 Zaidī, Dalāìl-e Vujūd-e Bārī-Ta'ālā, 14-43.

69 Zaidī, 28; Chittick, The Sufi Path of Knowledge, 96, 203-207; on occasionalism, see Dominik Perler and Ulrich Rudolph, Occasionalismus: Theorien der Kausalität im arabischislamischen und europäischen Denken (Göttingen: Vandenhoeck \& Ruprecht, 200o). On the Christian theological notion of creatio continua, see David Congdon, "Creatio Continua Ex Electione: A Post-Barthian Revision of the Doctrine of Creation Ex Nihilo," Koinonia 22 (2010): 33-53.

70 On this, see David Sedley, Creationism and its Critics in Antiquity (Berkeley: University of California Press, 2007), and Anna Marmodoro and Brian D. Prince, eds., Causation and Creation in Late Antiquity (Cambridge: Cambridge University Press, 2015).

71 'Abdullāh Javādī Āmulī, Tabyìn-e Barāhìn-e Is̉bāt-e Khudā (Qum: Markaz-e Nashr-e Isrā, $1384 \mathrm{Sh} / 2005$ ), 172-184; on the Aquinas ways, see Anthony Kenny, The Five Ways (London: Routledge Kegan \& Paul, 1969).

72 Zaidī, Dalä̀il-e Vujūud-e Bārī-Ta'ầlā, 50-52. 
cannot be an absolute first unmoved mover, since contingency and potentiality cannot arise in the very conception of God.

The second proof from creation (ḥudüs) engages the Muslim theologians' attempt to draw out the doctrine of God's creation of the cosmos out of nothing (creatio ex nihilo) that locates the cosmos in contingency as well as time. This, of course, led to the philosophical critiques that became known as the defence of the eternity of the cosmos and at that level the debate mirrored the one in late antiquity between Proclus and John Philoponus. This and the previous proof betray elements of teleological and cosmological arguments, which is why Mullā Ṣadrā and Javādī Āmulī do not consider them to be demonstrative. ${ }^{73}$ The cosmos is constantly in the process of becoming and in flux-Mullā Sadrā's doctrine of motion in the category of substance (harakah jauhariyyah), which points to the creaturely nature and essential contingency of the cosmos; it merely indicates the presence of some metaphysical entity that must be transcendent-it does not prove the existence of a God. ${ }^{74}$

The third type of classical proof is Avicenna's proof from contingency. After presenting it and citing the objections of Ġhazālī and Averroes, Zaidī discusses Mullā Ṣadrā’s objections, those of Suhravardī, and then Javādī Âmulī. It comes down to whether the assumption of the impossibility of infinite regress of actual causes is valid as well as Țūsìs famous Avicennian dictum of necessitarianism: "if it is not necessary, it does not exist" (lamyajib lamyüjad). ${ }^{75}$ To show his grasp of the philosophy of religion, Zaidī switches to the European traditions and the debate on sufficient reason between Leibniz and Kant. ${ }^{76}$ Mullā Șadra uses Avicenna's notion to develop his own idea of "the contingency of exigency" (imkān faqrī) which is a way of demonstrating the contingency of the cosmos. ${ }^{77}$ But again because all of these proofs begin with the contingent and the motive and ephemeral they cannot constitute solid demonstrations for the existence of God.

The fifth chapter is then Mullā Șadrā's famous ontological proof- "the demonstration of the veracious" (burhān ul-șiddiqinn) which suffices him. The demonstration relies upon the need for existence itself to be the middle term in the syllogistic inference and hence must respond to Suhravardìs famous critique that "existence" is merely a term with a sense but not a referent-it is not a

73 On these classes of arguments, see Graham Oppy, Arguing about Gods (Cambridge: Cambridge University Press, 2006), 97-240.

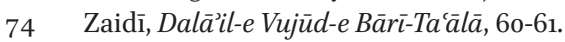

75 Zaidī, Dalăìl-e Vujūd-e Bārì-Táălā, 71-72.

76 Zaidī, Dalằil-e Vujūd-e Bārī-Ta'ālā, 75-79.

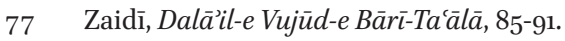


"real predicate."78 Zaidi also discusses the versions of the proofs in the work of Sabzavārī and Țabātabāì (1902-1981), and their attempts to modify and improve it. The real question that arises is whether this is in fact a proof, since it seems to rely upon an almost mystical intuition of the being of God. At the same time, it is somewhat odd that Zaidī goes on to compare it to the famous ontological argument of Anselm with which it shares little (and with the later versions and critiques of Descartes and Kant). ${ }^{79}$ He cannot leave it at mysticism, since the function of the book is to draw on philosophy to provide a response to contemporary intellectual challenges, at the heart of which is demonstrating the existence of God. He returns to the question of predication to defend the notion the existence does in fact refer, is a real predicate, and the proof relies upon the basic metaphysics of Mullā Șadrā: existence is ontologically fundamental, singular but modulated, and it can be directly intuited. ${ }^{80}$ Thus, the proof is located within the systematic coherence of Sadrian metaphysics.

A final appended chapter includes a full discursive listing of Mullā Șadrā's work, but it is neither critical (it includes pseudo-epigraphical works) nor does it add anything to the existing introductions to Mullā Șadrā. Zaidī seems to be writing for a bilingual readership, one that reads philosophy in English. Technical terms and names are often given with their English rendition as well, although they are not consistently rendered; for example, tashkik ul-vujūd (modulation of existence) in one place is "graded unity of being" and in another "systematic ambiguity of being."81 It is also extremely annoying, given the baggage of the term, to see hikmah muta'äliyah rendered as "transcendent theosophy," but that is clearly the influence of Nasr. ${ }^{82}$

Throughout the chapters, we see Zaidī drawing on Javādī Āmulìs analytical and quite excellent seminarian's approach to proofs for the existence of God entitled Tabyin-e Barāhinn-e Iśbāt-e Khudā, as well as comparisons to the arguments in philosophy of religion and in other traditions such as the quinque voces of Aquinas. Zaidī demonstrates his mastery of the text of Mullā Șadrā as well as the secondary literature and commentaries in Persian and English along with a decent grasp of the philosophy of religion and modern European philosophy (which may partly be derived from his reading of the Persian exegeses of the texts). As such it is a useful contribution in Urdu and seems to

\footnotetext{
78 Zaidī, Dalā̉il-e Vujūd-e Bārī-Táââā, 101-104.

79 Zaidī, Dalẳil-e Vujūd-e Bārī-Ta āâā, 105-115.

8o Zaidī, Dalāìl-e Vujūd-e Bārì-Ta'ālā, 120-125.

81 Zaidī, Dalằil-e Vujūd-e Bārī-Ta ālā, 17, 23.

82 Zaidī, Dalāill-e Vujūd-e Bārīi-Ta'ālā, passim.
} 
bridge those interested in the intellectual contributions of the Shi'i seminary with those seeking authentic Islamic alternatives to contemporary thought. In its understanding of the issues and the analytical nature of the presentationalthough it does not critique Mullā Ṣadrā at all—it is the best work on Mullā Șadrā in Urdu that one can find at present.

Apart from these works, there is some further evidence of interest in the philosophy of Mullā Șadrā, although it tends to be restricted to Shici intellectuals such as Abbas Hussaini, Barkatullah Sinovi and Hasnain Naqvi. All three run highly competent Urdu and English blogs on Sadrian thought as well as convening a bilingual Shia Islamic Philosophy Facebook group. ${ }^{83}$ While a small handful of blogs, websites, and a few books might not constitute a real intellectual wave-certainly they pale in significance compared to the very many glosses and seminary teaching hours dedicated to Mullā Șadrā in the Dars-e Nizāmī before independence- they nevertheless shed some light on elements of the pursuit of authenticity in the post-colonial state, particularly the desire to appropriate and adopt what they consider central and critical to their intellectual tradition. A fuller modern intellectual history of Pakistan and the "battle of ideas" since independence would require a much more extensive inquiry, interdisciplinary research, and would need to draw out the different modalities of philosophy and the life of the mind. But by adopting the study of Mullā Șadrā in Urdu as a heuristic device, we can still discern some contours of what constitutes philosophy in contemporary Pakistan, including its uses and abuses.

83 For the Facebook group, see https://www.facebook.com/groups/1708635152762098/about/ accessed June 14, 2019; for Hasnain Naqvi's blogs, see "Sadrian Metaphysics," Blogspot, accessed June 20, 2019, http://sadrianmetaphysics.blogspot.com; and "Illuminationist Philosophy," Wordpress, accessed June 20, 2019, https://illuminationistphilosophy .wordpress.com; and for Abbas Hussaini's blog, see "Abbas Hussaini," Blogfa, accessed June 12, 2019, http://abbashussaini.blogfa.com/post/159?fbclid=IwARıv7KgFiPE-Z43mfaH -OuE71P4aU5xIhIHEacdaTtvrO5n-At4iIoiDTEw. 